\title{
Analysing Climate Change Mitigation Policy Options in the Renewable Energy Sub-Sector in Tanzania
}

\author{
Ladislaus Kyaruzi ${ }^{1 *}$, Patrick M Ndaki ${ }^{2}$ and Richard YM Kangalawe ${ }^{3}$ \\ ${ }^{1}$ Institute of Resource Assessment, University of Dar es Salaam, Tanzania \\ ${ }^{2}$ Institute of Resource Assessment, University of Dar es Salaam, Tanzania \\ ${ }^{3}$ The Mwalimu Nyerere Memorial Academy, Tanzania \\ *Corresponding author, e-mail: leoky2009@gmail.com \\ Co-authors'e-mails: pattymzee@gmail.com; rkangalawe@hotmail.com
}

Received 21 Jun 2021, Revised 20 Sep 2021, Accepted 25 Sep 2021, Published Oct 2021

DOI: https://dx.doi.org/10.4314/tjs.v47i4.6

\begin{abstract}
Public policies influence reduction of greenhouse gas emissions. Also the extent to which policies are developed and implemented can influence the achievement of the national, regional and international climate change mitigation policy framework in the renewable energy sub-sector. This paper provides a critical overview of key policy options influencing the development of renewable energy sub-sector through climate change mitigation policy options in Tanzania. Questionnaire surveys were used to collect primary data from 100 relevant experts who represented 64 organizations in Tanzania. Secondary data were collected by literature review. The state of climate change mitigation policy options in the renewable energy sub-sector was assessed by using Statistical Product and Service Solutions (SPSS) version 26.0 and content analysis. The results showed Tanzania lacks adequate climate change mitigation policy and renewable energy policy frameworks. A specific national climate change policy and national renewable energy policy are needed to guide stakeholders to undertake climate change mitigation actions in the renewable energy sub-sector in Tanzania. Perceptions gained and recommendations made are essential for undertaking climate change mitigation actions in Tanzania, and can be relevant for other developing countries because of similar climate change mitigation contexts.
\end{abstract}

Keywords: climate change, renewable energy, greenhouse gases, policies, Tanzania.

\section{Introduction}

Historical and current increase of greenhouse gas emissions have significantly contributed to warming of the climate system. Globally, total human-caused surface temperature has increased by about 1.07 (0.8 to 1.3) ${ }^{\circ} \mathrm{C}$ from $1850-1900$ to $2010-2019$ (IPCC 2021). The total increase between the average of the 1850-1900 period and the 2003-2012 period was $0.78(0.72$ to 0.85$){ }^{\circ} \mathrm{C}$. In May 2019, the global land and surface temperature was $0.85^{\circ} \mathrm{C}$, and in August 2020 reached 0.94 ${ }^{\circ} \mathrm{C}$, an increase from 1880 to 2020 (NOAA 2019a, NOAA 2020). In 2017 global fossil carbon dioxide emissions rose between 34.2 and $38.2 \mathrm{GtCO}_{2}$ and in 2018 these emissions grew by 2.87 parts per million (ppm) (WMO 2019, NOAA 2019b). Global emissions in 2019 reached $59.1 \mathrm{GtCO}_{2}$ eq and the average annual growth is $1.4 \%$ since 2010 (UNEP 2020). There was a rapid increase of greenhouse gas emissions of $2.6 \%$ in 2019 due to an increase in vegetation forest fires (UNEP 2020). Specifically, IPCC (2021) indicates annual average increase of $410 \mathrm{ppm}$ for carbon dioxide $\left(\mathrm{CO}_{2}\right), 1866$ parts per billion (ppb) for 
methane $\left(\mathrm{CH}_{4}\right)$, and $332 \mathrm{ppb}$ for nitrous oxide $\left(\mathrm{N}_{2} \mathrm{O}\right)$ in 2019 .

Tanzania is among the developing countries striving to achieve socio-economic development and eradicate poverty in a sustainable manner (URT 2021a). As from $1^{\text {st }}$ July 2020, the country achieved status of a lower- middle-income country with gross national income per capital of US Dollars 1,080 (WB 2020). Achieving middle-income status implies strong and competitive economy supported by among others, strong industrial sector, adequate investment in physical infrastructure particularly road and railway networks, investment in energy, water, agriculture, tourism and telecommunications. Above all, these should be made cognisant of the sustainable use and management of natural resources along the lines of sustainable development goals with appropriate policies such as embracing the green economic growth agenda (URT 2000, 2016).

Despite the above efforts, climate change is a serious challenge in Tanzania and world causing major uncertainties in the implementation and certainly achievement of the Sustainable Development Goals (SDGs), including poverty eradication efforts (IPCC 2007a, Stern 2007, IPCC 2013, IPCC 2018, Tschakert et al. 2008). The United Nations community has recognized climate change as an urgent and irreversible threat that requires widest possible cooperation to accelerate reduction of global greenhouse gas emissions (UN 2016). Sustainable development (SD) is a fundamental strategy to guide the world's social and economic transformations. The four pillars of sustainable development are economy, society, environment and the fourth pillar is of culture, institutions, or governance (Biermann et al. 2014, Mori 2014, Shi et al. 2019). Alemaw and Simatele (2020) recognized the need for promoting inclusive and sustainable socio-economic development while simultaneously reducing greenhouse gas emissions. This can be achieved by adopting appropriate policies in the renewable energy sector in the country for economic growth and contribution to reduction of global greenhouse gas emissions. The United Nations Framework Convention on Climate Change and Paris Agreement (UN 1992, 2016) stipulate this requirement.

It is recognized that Tanzania has identified adaptation initiatives in renewable energy subsector that are promoting diversification of energy sources, supporting development and utilization of community based off-grids and mini-grids. Another adaptation initiative is promoting development and use of energy efficient technologies and behaviour (URT 2012, 2015a, 2021a, b). Mitigation initiatives in renewable energy sub-sector in the country include enhancing off-grid power supply to rural areas, use of renewable energy share in the national grid and off-grid (URT 2012, 2015a). IPCC (2007b) states that sustainable development involves comprehensive and integrated approach to economic, social and environmental processes. As stated by Sathaye et al. (2007), access to energy is critical as basic service in sustainable development. Additionally, IPCC (2007b) also states that sustainable development recognises the liberalization of energy sector that reduces costs and improves efficiency of energy sources. In energy investment, Tanzania plans to increase its energy-installed capacity with at least $1 \mathrm{GW}$ generated from renewable energy sources by 2025/2026 (MoE 2020, URT, 2021a). Tanzania targets to also have $70 \%$ by 2025/2026 of energy derived from renewable green energy of wind, solar, geothermal, biogas, and liquefied petroleum gas (LPG) and hydropower (URT 2016).

The objective of the study was to provide an assessment of the existing public policy options that promote climate change mitigation actions in the renewable energy sub-sector in Tanzania. In undertaking the assessment, categorization of policy options has been done in terms of feed-in-tariffs, share and access of independent renewable energy producers. The assessment also focused on energy mandates, tax exemptions, government grants, discounts, 
loans and guaranteed access from renewable energy sources.

\section{Materials and Methods}

This study was conducted in the regions of Dar es Salaam, Dodoma and Arusha in Mainland Tanzania (Figure 1). Mainland Tanzania is situated just south of the Equator, in the mid-eastern part of Africa between $1{ }^{\circ} \mathrm{S}$ to $12{ }^{\circ} \mathrm{S}$ and $29^{\circ} \mathrm{E}$ to $41^{\circ} \mathrm{E}$. Dar es Salaam region is located between $6^{\circ} 48$ ' 8.4708 "S and $39^{\circ} 16$ ' 46.4016 " E, Dodoma region is located between $6{ }^{\circ} 9$ ' 40.2624 'S and $35^{\circ} 44$ ' 43.5336 " $\mathrm{E}$ and Arusha region is located between $3{ }^{\circ} 23$ '12.9300 "S and $36{ }^{\circ} 40$ "58.7820" E. The basis for the selection of these regions was that most of the organisations dealing with climate change and renewable energy policies in the country are located in these regions (URT 2012, 2015a, b, 2021b).
Renewable energy sub-sector was carefully selected as a single case and provided compelling insights about patterns and processes for generation of critical knowledge about the study case (Bent 2001, George and Bennett 2005). Purposive selection of relevant organizations (Table 1) was employed because they provided insights into public policies process and practices in the renewable energy in Tanzania (Connolly 1998, Onwuegbuzie and Leech 2004). A sample size of 100 respondents came from 64 organizations based in Dar es Salaam (55\%), Dodoma (40\%) and Arusha $(5 \%)$. Organizations were presented as follows: government organizations (45\%); private sector (5\%); development partners (4\%); civil society organizations (20\%); media $(17 \%)$; research and academia $(9 \%)$ participated in the study.

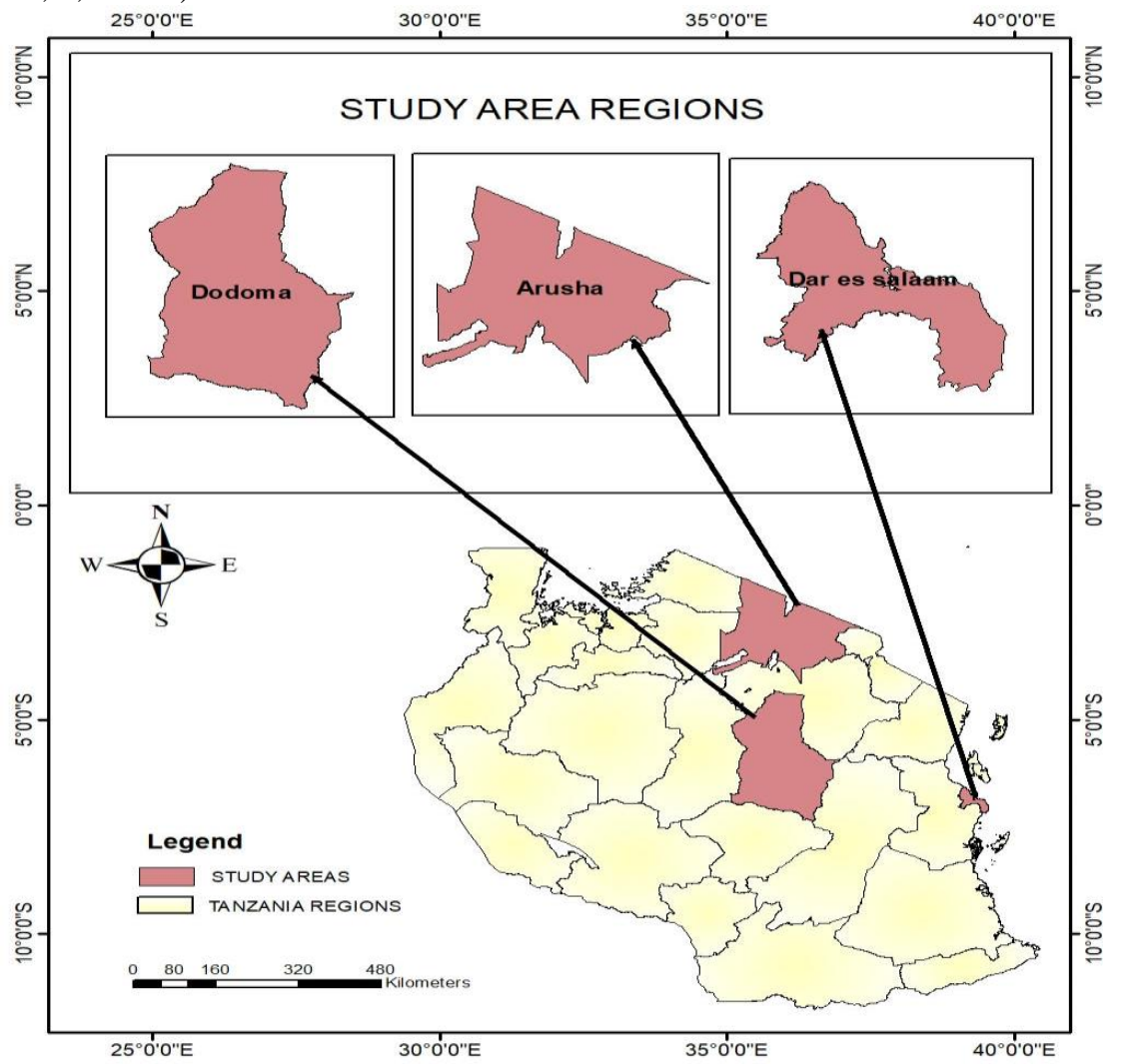

Figure 1: Location of study areas (Source: IRA-UDSM 2020). 
Data for the study were collected by surveys and literature review as a way to attract collective and creative interests (Chambers 1992). Questions in the questionnaire developed for this research were piloted prior to the main study (Mick et al. 2000). To ensure reliability and validity of data, the sources of study data included documents, archival records and questionnaires (Yin 1994, Verschuren and Doorewaard 1999).

By Statistical Product and Service Solutions Version 26.0, multiple response analyses were performed to understand how many people were aware of climate change mitigation policy and renewable energy policy options that promote renewable energy sub-sectors along with other options that the stakeholders may opt (Sabine and Brian 2004, IBM Corp. 2011, Arkkelin 2014) and content analysis (Berelson 1952, Abrahamson 1983). In order to understand whether or not there is a statistically significant relationship between the various renewable energy policy options and the actual development of renewable energy subsector, a Chi-Square test which included the symmetric measures of association (Phi, Cramer's V and Contingency Coefficient) was performed. These two statistical tests were important in order to highlight policy recommendations based on the level of significance and association between theoretical and observed assumptions for climate change mitigation, especially through promotion of renewable energy sub-sector.

Table 1: Organizations consulted during data collection

\begin{tabular}{lcc}
\hline Organisations & Number consulted & Percent \\
\hline Government Ministries & 8 & 12.5 \\
Government Agencies & 8 & 12.5 \\
Local Government Authority & 2 & 3.1 \\
Private Sector & 5 & 7.8 \\
Development Partners & 4 & 6.3 \\
Civil Society Organizations & 19 & 29.7 \\
Media & 14 & 21.9 \\
Research And Academia & 4 & 6.3 \\
Total & $\mathbf{6 4}$ & $\mathbf{1 0 0}$ \\
\hline
\end{tabular}

Source: Field data of the research (December 2019-March 2020).

\section{Results and Discussion}

\section{Demographic information of participants of} the study

Sixty eight percent $(68 \%)$ respondents were men, while $32 \%$ of the respondents were women, which may reflect of what women position might look like at work places. Middle aged (41-50 years) dominated by $38 \%$ followed by the age between $30-40$ years (28\%). This range of ages is believed to be a generation energetically working. The age of 51-60 years was represented by $22 \%$, while respondents with age below 30 years were $8 \%$ and minority (4\%) representation had age above 60 years. Moreover, majority of the respondents (74\%) had post-graduate education level which means they had enough knowledge and insights concerning issues of climate change mitigation policies at their respective offices. Respondents with underground level were $14 \%$, while respondents with certificate/diploma were only $12 \%$. Larger proportion of respondents came from government institutions (45\%) who are policy makers, while civil society organizations and media were $20 \%$ and $17 \%$ of respondents, respectively. Research and academia were represented by $9 \%$, private sector $5 \%$ and development partners $4 \%$. Larger proportion of respondents had working experience between $5-10$ years $(28 \%)$ and less than 5 years $(27 \%)$. Other respondents (28\%) had a good working experience between 10-20 years, while $11 \%$ had working experience between 20-25years. Only $1 \%$ of the respondents had working 
Kyaruzi et al. - Analysing climate change mitigation policy options in the renewable energy ...

experience between 25-30 years and there were years (Table 2).

$5 \%$ of respondents with experience above 30

Table 2: Sample profile

\begin{tabular}{|c|c|c|}
\hline Demographic variable & Number of respondents & Percent \\
\hline \multicolumn{3}{|l|}{ Gender } \\
\hline Male & 68 & 68 \\
\hline Female & 32 & 32 \\
\hline Total & 100 & 100 \\
\hline \multicolumn{3}{|l|}{ Age } \\
\hline Less than 30 years & 8 & 8 \\
\hline $30-40$ years & 28 & 28 \\
\hline 41-50 years & 38 & 38 \\
\hline $51-60$ years & 22 & 22 \\
\hline Above 60 years & 4 & 4 \\
\hline Total & 100 & 100 \\
\hline \multicolumn{3}{|l|}{ Education level } \\
\hline Certificate/Diploma level & 12 & 12 \\
\hline Undergraduate & 14 & 14 \\
\hline Post graduate & 74 & 74 \\
\hline Total & 100 & 100 \\
\hline \multicolumn{3}{|l|}{ Organisation/Affiliation } \\
\hline Government Ministry & 24 & 24 \\
\hline Government Agency & 19 & 19 \\
\hline Local Government Authorities & 2 & 2 \\
\hline Private sector & 5 & 5 \\
\hline Development partner & 4 & 4 \\
\hline Non-Government organization & 20 & 20 \\
\hline Media & 17 & 17 \\
\hline Research and academia & 9 & 9 \\
\hline Total & 100 & 100 \\
\hline \multicolumn{3}{|l|}{ Work experience } \\
\hline Less than 5 years & 27 & 27 \\
\hline $5-10$ years & 28 & 28 \\
\hline $10-15$ years & 16 & 16 \\
\hline $15-20$ years & 12 & 12 \\
\hline $20-25$ years & 11 & 11 \\
\hline $25-30$ years & 1 & 1 \\
\hline Above 30 years & 5 & 5 \\
\hline Total & 100 & 100 \\
\hline
\end{tabular}

Source: Field data of the research (December 2019 - March 2020).

The relationship between development of the renewable energy sub-sector in Tanzania and existing policy options that promote renewable energy sub-sector development as measured using the Pearson Chi-Square test (which was found to be 0.003 ) was statistically significant. There were higher levels of associations as indicated by the values of symmetric measures (Phi, Cramer's V and Contingency Coefficient) which stood at 0.003 as well (Tables 3 and 4). This supports the hypothesis that higher levels of awareness of 
different policy options among stakeholders including investors could greatly influence the development of renewable energy sub-sector and contribute to climate change mitigation efforts in the country.

Table 3: Chi-Square test results

\begin{tabular}{lccc}
\hline & Value & df & Asymp. Sig. (2-sided) \\
\hline Pearson Chi-Square & $25.368^{\text {a }}$ & 9 & $\mathbf{0 . 0 0 3}$ \\
Likelihood ratio & 25.706 & 9 & 0.002 \\
Linear-by-linear association & 15.765 & 1 & 0.000 \\
N of valid cases & 100 & & \\
\hline
\end{tabular}

a. 9 cells $(56.2 \%)$ have expected count less than 5. The minimum expected count is .80 .

Source: Field data of the research (December 2019-March 2020)

Table 4: Symmetric measures

\begin{tabular}{|c|c|c|c|c|c|}
\hline & & Value & $\begin{array}{l}\text { Asymp. Std. } \\
\text { Error }^{\mathrm{a}}\end{array}$ & $\begin{array}{c}\text { Approx. } \\
\mathrm{T}^{\mathrm{b}} \\
\end{array}$ & $\begin{array}{l}\text { Approx. } \\
\text { Sig. }\end{array}$ \\
\hline Nominal by & Phi & 0.504 & & & 0.003 \\
\hline \multirow[t]{3}{*}{ Nominal } & Cramer's V & 0.291 & & & 0.003 \\
\hline & Contingency & 0.450 & & & 0.003 \\
\hline & Coefficient & & & & \\
\hline Interval by Interval & Pearson's R & 0.399 & 0.081 & 4.308 & $0.000^{\mathrm{c}}$ \\
\hline Ordinal by Ordinal & Spearman Correlation & 0.405 & 0.084 & 4.391 & $0.000^{\mathrm{c}}$ \\
\hline $\mathrm{N}$ of valid cases & & 100 & & & \\
\hline
\end{tabular}

${ }^{\mathrm{a}}$ Not assuming the null hypothesis; ${ }^{\mathrm{b}}$ Using the asymptotic standard error assuming the null hypothesis; ${ }^{\mathrm{c}}$ Based on normal approximation.

Source: Field data of the research (December 2019-March 2020).

Table 5 presents the results from multiple response analysis of the policy options. The results show that there is a general awareness of various policy options that influence development of the renewable energy subsector in Tanzania. Feed-in-tariffs (40.8\%), energy mandates $(30.3 \%)$ and government discounts to renewable energy technologies investments $(36.8 \%)$ were least popular among experts. This indicates a need of more training and awareness programs to the public about how to invest and use renewable energy (Bishoge et al. 2019). The results imply these policy options exist but stakeholders undertake climate change mitigation actions within their mandates. The findings are supported by IPCC (2011) that requires governments to introduce feed-in-tariffs as a policy option to promote renewable energy integration in to energy systems. However, although this policy option exists in the country, they are not implemented adequately due to low awareness of the public and inadequate enforcement because most of organisations tend to deal with policy options where they have mandate. One policy option might be operational in one area while not in others including the actors where some actors may be well familiar with a policy option or part of the policy option or not.

The results imply also energy mandates in the context of setting the targets of renewable energy sources in the cities are not operational in the country. In this regard, requirement on renewable energy targets as recommended by other scholars for instance Peter and Yang (2019) on cities is not met in the country. The results also imply that although the government provides discounts to renewable energy resources development, the policy option is not effectively implemented. 
Kyaruzi et al. - Analysing climate change mitigation policy options in the renewable energy ...

Table 5: Multiple response analysis of the policy options

\begin{tabular}{|c|c|c|c|}
\hline \multirow{2}{*}{$\begin{array}{l}\text { Policy options that influence the development of the } \\
\text { renewable energy sub-sector }\end{array}$} & \multicolumn{3}{|c|}{ Measure of frequencies } \\
\hline & $\begin{array}{l}\text { Number of } \\
\text { responses }(\mathrm{n})\end{array}$ & Percent & $\begin{array}{l}\text { Percent of } \\
\text { cases }\end{array}$ \\
\hline $\begin{array}{l}\text { Feed-in-tariffs (i.e. long-term contracts to renewable } \\
\text { energy producers, renewable energy technologies } \\
\text { awarded a lower per-kwh price) }\end{array}$ & 31 & 9.3 & 40.8 \\
\hline $\begin{array}{l}\text { Share of renewable energy sources in national grid } \\
\text { energy mix }\end{array}$ & 58 & 17.0 & 76.3 \\
\hline $\begin{array}{l}\text { Independent renewable energy producers enabled to } \\
\text { access national grid }\end{array}$ & 40 & 12.0 & 52.6 \\
\hline $\begin{array}{l}\text { Energy mandates (relevant laws mandating targets of } \\
\text { renewable energy to cities) }\end{array}$ & 23 & 6.9 & 30.3 \\
\hline $\begin{array}{l}\text { Tax exemption to renewable energy technologies or } \\
\text { investments }\end{array}$ & 42 & 12.7 & 55.3 \\
\hline $\begin{array}{l}\text { Government grants to renewable energy technologies } \\
\text { or investments }\end{array}$ & 36 & 10.8 & 47.4 \\
\hline $\begin{array}{l}\text { Government discounts to renewable energy } \\
\text { technologies investments }\end{array}$ & 28 & 8.4 & 36.8 \\
\hline Provision of loans to renewable energy investments & 39 & 11.7 & 51.3 \\
\hline Guaranteed access from renewable energy sources & 35 & 10.5 & 46.1 \\
\hline Total & 332 & 100 & 436.8 \\
\hline
\end{tabular}

a. Dichotomy group tabulated at value 1 .

Source: Field data of the research (December 2019-March 2020).

However, share of renewable energy sources in national grid energy mix $(76.3 \%)$, access to national grid by independent power producers $(52.6 \%)$ and tax exemption to renewable energy technologies or investments $(55.3 \%)$ are the most known policy options among experts. This understanding implies that although access to national grid and tax exemption to renewable energy technologies and investments exists in the country are not implemented effectively. This is because the level of awareness is not as higher as would be expected.

The policy option on government grants to renewable energy technologies or investments is also the most known policy option among experts $(47.4 \%)$ although not as much as would be expected. This raises some concerns whether the public knows the policy option or some organizations concentrate to policies they deal with within their mandate.

Provision of loans to renewable energy investments is the most known policy option among the experts (51.3\%). IPCC (2011) requires governments to introduce direct government payments such as loans as policy option that promotes renewable energy integration into energy systems. Guaranteed access from renewable energy sources was also found to be the most known policy option among the experts (46.1\%). The findings also establish that the government supports independent power producers including the access to the national grid. Government supports independent power producers including the national grid access. For example, in the year 2019/2020, 12 small solar projects of $317.78 \mathrm{~kW}$ capacity were registered by the government to be implemented by Power Corner (T) Ltd and PowerGen Renewable Energy Ltd companies (MoE 2020). Mwenga Hydro Ltd Company has also been granted a short licence to produce the hydropower of $2.5 \mathrm{MW}$ and sell its power to its neighbouring rural areas through the national grid (MoE 2020). Ngaira and Omwayi (2012) 
recognized developing countries need to encourage investments by independent power producers to develop renewable energy plants to supply energy to rural areas where majority of the people live. This implies rural areas because of their off-grid connections; they use renewable energy technologies such as solar technologies and mini-hydro. In so doing, they reduce the use of fossil fuels. The results from the study (Table 5) generally, reveal that the country is in line with IPCC (2011) where governments are required to introduce direct government payments such as grants and rebates, loans and guarantees policies that promote renewable energy integration into energy systems.

\section{Conclusions}

There is a general awareness of various policy options that influence development of the renewable energy sub-sector in Tanzania. However, the findings reveal that the government needs to further engage the stakeholders to provide innovative actions in the implementation of climate change mitigation policy options in the context of renewable energy resources development.

The study showed there are climate change mitigation policies that exist in Tanzania. Feedin-tariffs exist but there is low awareness of their existence in the country. The country allows shares of renewable energy sources in the national grid energy mix but the policy option is not known to non-state actors. Power produced from renewable energy sources is guaranteed access to the national energy grid. The government provides grants to renewable energy technologies and investments and there are government discounts to renewable energy technologies and investments in the country. Although discounts exist, most of the national renewable energy actors are not aware if government provides discounts to renewable energy technologies and investments in the country. Given the existing policy situation, legal and policy reform is proposed to accommodate the existing challenges posed by climate change in the country. Robust national climate change policy should be adopted with clear roles of actors. It is foreseen the policy framework will influence climate change mitigation actions in the renewable energy subsector in the country. The policy should be supported by enacted law specifically on climate change that will ensure binding and mandatory requirements for taking climate change mitigation actions. The country needs to adopt a specific national renewable energy policy to promote development of renewable energy resources. The study assumes renewable energy policy will improve national climate change policy framework.

\section{Acknowledgements}

This study is part of a PhD study by the first author. We are thankful to the University of Dar es Salaam for hosting this study. The authors acknowledge officials from various organisations for their valuable time and commitment during data collection for this study.

Declaration of Interest: Authors declare there is no potential competing or conflicting interests regarding publication of the work.

\section{References}

Abrahamson M 1983 Social research methods. Englewood Cliffs, NJ: Prentice Hall.

Alemaw BF and Simatele D 2020 Integrating Climate Change Adaptation and Mitigation into Sustainable Development Planning: The Policy Dimension. In: Matondo J, Alemaw B, Sandwidi W (Eds.) Climate Variability and Change in Africa. Sustainable Development Goals Series. Springer, Cham.

Arkkelin D 2014 Using SPSS to Understand Research and Data Analysis. Psychology Curricular Materials. Book 1. http://scholar.valpo.edu/psych_oer/1: 96, 143.

Bent F 2001 Making Social Science Matter: why social enquiry fails and how it can succeed again, Cambridge University Press, $\mathrm{x}+204$ pp. $£ 37.50, £ 13.95$ (pbk.). JSP, 31 .

Berelson B 1952 Content Analysis in Communication Research. Glencoe, III: The Free Press: 18. 
Biermann F, Stevens C, Bernstein S, Gupta A, Kabiri N, Kanie N, Levy M, Nilsson M, Pintér L, Scobie M 2014 Integrating Governance into the Sustainable Development Goals. Policy Brief: 4.

Bishoge OK, Zhang L and Mushi WG 2019 The potential renewable energy for sustainable development in Tanzania: A review. Clean Technologies 1(1): 70-88.

Chambers R 1992 Participatory Rural Appraisal. Institute of Development Studies, UK, University of Sussex.

Connolly P 1998 Dancing to the wrong tune': Ethnography generalization and research on racism in schools. Open University Press Buckingham, UK: 122-139.

George AL and Bennett AO 2005 Case studies and theory development in the social sciences. Mit Press.

IBM Corp 2011 IBM SPSS Statistics for Windows, Version 20.0. IBM Corp., Armonk, New York.

Intergovernmental Panel on Climate Change [IPCC] 2007a Climate Change 2007: Mitigation of Climate Change. Contribution of Working Group III to the Fourth Assessment Report of the Intergovernmental Panel on Climate Change. Cambridge, University Press: 851.

IPCC 2007b Fourth Assessment Report on Climate Change 2007: The Physical Science Basis. Intergovernmental Panel on Climate Change.

IPCC 2011 Special Report on Renewable Energy Sources and Climate Change Mitigation (SRREN). [Report]. IPCC.

IPCC 2013 Climate Change: The Physical Science Basis. Contribution of Working Group I to the Fifth Assessment Report of the Intergovernmental Panel on Climate Change. In: Stocker TF, Qin D, Plattner GK, Tignor M, Allen SK, Boschung J, Nauels A, Xia Y, Bex V and Midgley PM (Eds.)]. Cambridge University Press, Cambridge, United Kingdom and New York, NY, USA, 1535: 11-13

IPCC 2018 Summary for Policymakers. In: Global warming of $1.5^{\circ} \mathrm{C}$. An IPCC Special Report on the impacts of global warming of $1.5{ }^{\circ} \mathrm{C}$ above pre-industrial levels and related global greenhouse gas emission pathways, in the context of strengthening the global response to the threat of climate change, sustainable development, and efforts to eradicate poverty. In: Masson-Delmotte V, Zhai P, Pörtner HO, Roberts D, Skea J, Shukla PR, Pirani A, Moufouma-Okia W, Péan C, Pidcock R, Connors S, Matthews JBR, Chen Y, Zhou X, Gomis MI, Lonnoy E, Maycock $\mathrm{T}$, Tignor $\mathrm{M}$ and Waterfield $\mathrm{T}$ (Eds.)]. World Meteorological Organization, Geneva, Switzerland: 8, 32.

IPCC 2021 Summary for Policymakers. In: Climate Change 2021: The Physical Science Basis. Contribution of Working Group I to the Sixth Assessment Report of the Intergovernmental Panel on Climate Change [Masson-Delmotte V, Zhai P, Pirani A, . Connors SL, Péan C, Berger S, Caud N, Chen Y, Goldfarb L, Gomis MI, Huang M, Leitzell K, Lonnoy E, Matthews JBR, Maycock TK, Waterfield T, Yelekçi O, Yu R and Zhou B (Eds)]. Cambridge University Press. In Press: 5-6.

Mick F, Martin E and Mike W 2000 Tourism and leisure research methods: data collection, analysis and interpretation. Longman.

Ministry of Energy [MoE] 2020 Budget Speech for Year 2020/21 of the Ministry of Energy. Dodoma: 7-23, 50-51.

Mori K 2014 Global Justice in the Anthropocene: The Fourth Pillar Debate in Sustainable Development. J. Soc. Sci. 7: 101-122.

National Oceanic and Atmospheric Administration [NOAA] 2019a Global Climate Report - May 2019. State of the Climate. National Centers for Environmental Information (NCEI). [Online] Available at: https://www.ncdc.noaa.gov/sotc/global/20190 5 [Accessed 16 Aug. 2019].

Ngaira JKW and Omwayi K 2012 Climate change mitigation: Challenges of adopting the green energy option in the Lake Victoria basin. Int. J. Phys. Sci. 7(41): 5615-5623.

NOAA 2019b Global carbon dioxide growth in 2018 reached 4th highest on record | National Oceanic and Atmospheric Administration. [Online] Available at: https://www.noaa.gov/news/global-carbondioxide-growth-in-2018-reached-4th-higheston-record [Accessed 16 Aug. 2019]. 
NOAA 2020 National Centers for Environmental information, Climate at a Glance: Global Time Series, published September 2020, retrieved on October 1, 2020 from https://www.ncdc.noaa.gov/cag/.

Onwuegbuzie AJ and Leech NL 2004 Enhancing the Interpretation of Significant Findings: The Role of Mixed Methods Research. The Qualitative Report 9(4): 770-792.

Peter LL and Yang Y 2019 Urban planning historical review of master plans and the way towards a sustainable city: Dar es Salaam, Tanzania. Front. Architect. Res. 8(3): 359377.

Sabine L and Brian SE 2004 A handbook of statistical analyses using SPSS: 43.

Sathaye J, Najam A, Cocklin, HT, Lecocq F, Llanes-Regueiro J, Pan J, Petschel-Held G, Rayner S, Robinson J, Schaeffer R, Sokona Y, Swart R, Winkler H 2007 Sustainable Development and Mitigation. In Climate Change 2007: Mitigation. Contribution of Working Group III to the Fourth Assessment Report of the Intergovernmental Panel on Climate Change. In: Metz B, Davidson OR, Bosch PR, Dave R and Meyer LA (Eds). Cambridge University Press, Cambridge, United Kingdom and New York, NY, USA.

Shi L, Han L, Yang F and Gao L 2019 The evolution of sustainable development theory: types, goals, and research prospects. Sustainability 11: 7158

Stern N 2007 Report on the Economics of climate change. Cambridge University Press.

Tschakert P, Huber-Sannwald E, Ojima DS, Raupach MR, Schienke E 2008 Holistic, Adaptive Management of the Terrestrial Carbon Cycle at Local and Regional scales.

UN 1992 United Nations Framework on Climate Change. [Convention]. United Nations, New York.

UN 2016 The Paris Agreement. United Nations Framework Convention on Climate Change Secretariat. Bonn. [Online] Available at: https://unfccc.int/process-and-meetings/theparis-agreement/the-paris-agreement

[Accessed 4 Feb. 2019]. UNFCCC Secretariat: 3 .

United Nations Environment Programme [UNEP] 2020 Emissions Gap Report 2020. UNEP.

United Republic of Tanzania [URT] 2000 The Tanzania Development Vision 2025. [Online] Available at: http://www.mof.go.tz/mofdocs/overarch/visio n2025.htm [Accessed 17 July 2019 Planning Commission]. Dar es Salaam: 14

URT 2012 National Climate Change Strategy. Vice President's Office: 13, 55-63.

URT 2015a Intended Nationally Determined Contributions. Vice President's Office: 3-7.

URT 2015b National Energy Policy. Ministry of Energy. Dar es Salaam.

URT 2016 National Five Year Development Plan 2016/17-2020/21. Ministry of Finance and Planning: 59.

URT 2021a National Five Year Development Plan 2021/22 - 2025/26. Ministry of Finance and Planning, Dodoma.

URT 2021b National Climate Change Response Strategy (2021-2026). Vice President's Office, Division of Environment, Government Printer, Dodoma. Tanzania: 27-33, 49, 95-97.

Verschuren P and Doorewaard H 1999 Designing a Research Project. Utrecht: LEMMA.

World Bank [WB] (2020) Overview. [Online] Available at: <https://www.worldbank.org/en/country/tanza nia/overview> [Accessed 25 November 2020]. Washington, DC: World Bank.

World Meteorological Agency [WMO] 2019 Global Carbon Budget: Carbon Budget 2019. [Online] Available at: https://public.wmo.int/en/media/news/globalcarbon-budget-shows-rise-emissions [Accessed 7 Jul. 2019].

Yin RK 1994 Case study research: Design and methods ( $2^{\text {nd }}$ Ed.). Newbury. 